\title{
Predictors of Preference for the Exported Campus Model of Study Abroad
}

\section{Susan B. Goldstein \\ University of Redlands}

Since the early 1960s, there has been a steady increase in the number of students enrolled in institutions of higher education outside of their home countries. According to the Organisation for Economic Co-operation and Development, the number of study abroad students worldwide more than doubled between 2000 and 2012, with an average annual growth rate of almost 7\% (OECD, 2014). In the United States, over 289,000 students participated in international programs in 2014, a three-fold increase over the previous two decades (Open Doors, 2014). Many tertiary institutions, particularly in the U.S., have addressed this increased demand for study abroad experiences by incorporating exported campus ${ }^{1}$ or "island" programs into their study abroad options (Engle \& Engle, 2003; Maharaja, 2009). Although study abroad has traditionally emphasized language and cultural immersion, the exported campus model typically involves transporting students and faculty from a single university to a self-contained community within the host culture. These students generally study and live exclusively with members of their home institution on a campus run by that institution (Norris \& Dwyer, 2005).

The efficacy of the exported campus model in terms of advancing intercultural competence and language proficiency has been of considerable debate in the study abroad community (Fry, Paige, Jon, Dillow, \& Nam, 2009; Wolcott, 2013), with some questioning the degree to which students in these environments achieve the same level of culture learning as those in more immersive programs. Yet, investigators of exported campus programs have outlined several advantages of this model, including (1) greater accessibility to study abroad for students with limited language proficiency or cross-cultural experience, (2) pre-approved curricula that are consistent with the home institution's academic requirements, (3) programs scheduled to fit the duration and timing of the home campus term, (4) the potential for including innovative experiential courses tailored to the needs and interests of study abroad participants, (5) a group context that facilitates own-culture learning, as U.S. students work together to process new perspectives on American culture, (6) tuition and fees that are kept within the institution, rather than paid to outside entities, and (7) an easily accessible mechanism for faculty development (Hanouille \& Leuner, 2001; Nelson \& Rapoport, 2005; Tretheway, 1992; Woolf, 2007).

The few empirical outcome studies of exported campus programs point to three general findings. First, students who participate in these programs appear to develop greater intercultural competence than those who do not participate in study abroad. Maharaja (2009), for example, found that students who participated in a semester-long exported campus program had greater gains in intercultural sensitivity and cross-cultural adaptability than their on-campus counterparts. Second, exported

\footnotetext{
${ }^{1}$ Nelson and Rapoport (2005, Abstract) indicate that the term "exported campus" has been used to refer to the "island model" of study abroad. Given that the term "island model" may produce negative connotations for some readers, the term "exported campus model" was adopted for this article.
} 
campus programs may be particularly effective when supported by such interventions as pre-departure courses and in-country experiential activities (Paige \& Vande Berg, 2012). And third, more immersive models are not necessarily superior to exported campus programs. Results of the extensive Georgetown Consortium study of U.S. study abroad participants (Vande Berg, Connor-Linton, \& Paige, 2009) challenged the idea that there is a direct relationship between level of immersion and culture learning. In fact, "students who took courses alongside other U.S. students, or in classes featuring a mixture of U.S., host culture, and other international students, showed greater IDI [Intercultural Development Inventory] gains than students who studied in courses made up entirely of host country students" (p. 21). These authors emphasized the need for achieving a balance between a challenging and a supportive environment: "Students, at one extreme, those who spent much of their free time with other U.S. nationals were interculturally underchallenged and actually became slightly more ethnocentric while abroad. Students at the other extreme spent so much time with host country nationals that they became interculturally overwhelmed, lost ground in their IDI scores, becoming more ethnocentric" (p. 24). Thus, one critical function of an exported campus program is to support interactions with the host culture outside of the classroom (Nelson \& Rapoport, 2005). As Hanouille and Leuner (2001) suggested, these programs may serve as "a repository of experience providing helpful do's and don'ts relative to interaction with the surrounding community" (para. 9) and that "rather than insolating and isolating their students, [these programs act] to direct and facilitate access to local culture, whether academic or social" (para. 8).

The degree to which the support offered by exported campus programs is necessary, or even desired, by participants may depend on individual differences in personality, attitudes, and skills. Students who have greater difficulty adjusting to new environments or are less interculturally competent, for example, may be particularly well served by and drawn to the exported campus model. Li, Olson, and Frieze (2013) suggested that a better understanding of study abroad participants' characteristics is required for effective program development and recruitment. Thus, it is important to identify any pre-existing characteristics of the students who prefer exported campus programs as opposed to programs with a greater degree of immersion. Just as the cultural fit between a sojourner's personality profile and host culture norms facilitates psychological well-being (Searle \& Ward, 1990; Ward \& Kennedy, 1993), the fit between the student's individual attributes and the characteristics of a study abroad program may also be key to successful adjustment. If students who prefer the exported campus model differ in meaningful ways from those who prefer programs with greater immersion, this information could be of use to practitioners involved in designing and conducting study abroad and pre-departure programs as well as to researchers investigating program outcomes. The goal of the current study is to investigate demographic, personality, and intercultural characteristics of students who prefer the exported campus model of study abroad over a more immersive experience.

Given the absence of research on predictors of preference for types of study abroad programs, variables were selected by relying upon predictors of intercultural adjustment and/or participation in study abroad programs (Goldstein \& Kim, 2006; Stroud, 2010; Ward, Bochner, \& Furnham, 2001), including self-efficacy, adventurousness, tolerance for ambiguity, intercultural communication apprehension, ethnocentrism, language learning interest, and cross-cultural competence.

\section{Self-efficacy}

Bandura (1977, p. 193) defined self-efficacy as "the conviction one can engage in behavior that 
will produce the desired outcome." Research on general self-efficacy explores feelings of personal competence in dealing with novel tasks and coping with a broad range of challenging or stressful situations (Luszczynska, Scholz, \& Schwarzer, 2005). Cross-cultural research on self-efficacy has found consistent positive associations with optimism, self-regulation, and self-esteem and negative associations with depression and anxiety (Luszczynska, Gutiérrez-Doña, \& Schwarzer, 2005). Efficacy beliefs contribute significantly to the level of motivation and performance in a wide variety of contexts (Bandura \& Locke, 2003), including those involving intercultural adjustment (e.g., Harrison, Chadwick, \& Scales, 1996; Hechanova-Alampay, Beehr, Christiansen, \& van Horn, 2002; Li \& Gasser, 2005; Wilson, Ward, \& Fischer, 2013). Students who select an exported campus program may do so in part because they feel ill equipped to cope with the challenges of a more immersive situation. Thus, individuals who prefer the exported campus model were expected to have lower self-efficacy than those who prefer a more immersive experience.

\section{Adventurousness}

Adventurousness is a facet of the Five Factor Model dimension Openness to Experience. Of the Five Factor Model dimensions, openness to experience is perhaps most often identified as an important intercultural trait (Caligiuri, 2000; Leung, Ang, \& Tan, 2014). McCrae and Costa (1987) described openness to experience as characterized by having original, imaginative broad interests, and a sense of daring which can manifest in fantasy, aesthetics, feelings, actions, ideas, and values. Openness to experience is associated with a decreased tendency to view intercultural situations as threatening (Van der Zee \& van Oudenhoven, 2013). Bakalis and Joiner (2004), for example, found that Australian exchange students had higher openness scores than a comparison group of students who chose not to study abroad. Of the various facets of openness to experience, perhaps most relevant to the choice of study abroad model is adventurousness, which focuses on willingness to try new things. Li, Olson, and Frieze (2013), for example, found an association between intent to study abroad and neophilia, or desire for new experiences. Given the likelihood that a more immersive experience is likely to involve encountering more unfamiliar events, the trait of adventurousness may predict not only interest in study abroad, but desired degree of immersion. Thus, individuals who prefer the exported campus model were expected to have lower adventurousness than those who prefer a more immersive experience.

\section{Tolerance for Ambiguity}

Budner (1962) defined intolerance of ambiguity as a tendency to perceive ambiguous situations as a source of threat. Tolerance for ambiguity is reported to be a correlate of favorable intergroup attitudes (Chen \& Hooijberg, 2000; Strauss, Connerley, \& Ammermann, 2003) and participation in study abroad (Bakalis \& Joiner, 2004) and is a component of intercultural competence and adaptation (Cui \& Awa, 1992; Leong \& Ward, 2000; Lloyd \& Härtel, 2010). Tolerance for ambiguity is also associated with a tendency to seek information from a variety of sources rather than those that confirm one's views (Gudykunst \& Kim, 1997). It seems likely that more immersive programs would be associated with exposure to a greater range of perspectives and increased uncertainty. Thus, individuals who prefer the exported campus model were expected to have lower tolerance for ambiguity than those who prefer a more immersive experience.

\section{Intercultural Communication Apprehension}

Neuliep and McCroskey (1997a) used the term "intercultural communication apprehension" to 
describe anxiety associated with real or anticipated interaction with others of different cultural backgrounds from oneself. This anxiety may be a product of the novelty and dissimilarity associated with such intercultural contact situations (Neuliep \& Ryan, 1998). Intercultural communication apprehension was found to be inversely correlated with a measure of "intercultural willingness-tocommunicate" (Lin \& Rancer, 2003) and with positive expectations of study abroad (Goldstein \& Kim, 2006). Communicating with culturally different individuals is a key component of the study abroad experience and may be expected to increase with level of immersion. It seems, then, that individuals with a high level of intercultural communication apprehension would be more likely to avoid participating in an immersive study abroad experience. Thus, individuals who prefer the exported campus model were expected to have higher intercultural communication apprehension than those who prefer a more immersive experience.

\section{Ethnocentrism}

Neuliep and McCroskey (1997b, p.385) identified ethnocentrism as "one of the central concepts in understanding outgroup attitudes and intergroup relations...". Definitions of ethnocentrism focus on a universal tendency to evaluate other cultures using standards from one's own value system. In one of the earliest definitions, Sumner (1906, p.13) described ethnocentrism as the "...view of things in which one's own group is the center of everything, and all others are scaled and rated with reference to it." Bizumic and Duckitt (2012) suggested that ethnocentrism has at its core ethnic group selfcenteredness and self-importance and is distinct from outgroup negativity. Uhlmann (2012, p. 381) identified an ethnocentric perspective unique to the U.S. labeled "American psychological isolationism," which involves "a distinctive cultural mindset characterized by a lack of regard for and even lack of awareness of the perspectives of other countries, coupled with a passionate desire to spread American values throughout the world."

Ethnocentrism is a predictor of participation in study abroad (Goldstein \& Kim, 2006) and of willingness to interact with culturally different others (Logan, Steel, \& Hunt, 2015), in that it may result in the tendency to "...intentionally circumvent communication with persons of different cultures" (Neuliep, 2002, p. 203). Students with higher levels of ethnocentrism may see less value in learning about the cultural practices of others, particularly if it involves a challenging, immersive situation. Thus, individuals who prefer the exported campus model were expected to have higher ethnocentrism than those who prefer a more immersive experience.

\section{Language Learning Interest}

Interest in language learning is associated with seeking intercultural contact and knowledge. Individuals who express interest in language learning are more likely to attend international programs on campus, discuss international issues inside and outside of the classroom (Hembroff \& Rusz, 1993) and are more likely to participate in study abroad programs (Carlson, Burn, Useem, \& Yachimowicz, 1990; Goldstein \& Kim, 2006). Exported campus programs may attract students, in part, because they generally have fewer language proficiency requirements and these students may not view language and culture learning as inextricably linked. Thus, individuals who prefer the exported campus model were expected to have lower interest in language learning than those who prefer a more immersive experience. 


\section{Cross-Cultural Competence}

Deardorff (2006, pp. 247-8) described cross-cultural competence as "the ability to communicate effectively and appropriately in intercultural situations based on one's intercultural knowledge, skills, and attitudes." Cultural intelligence (CQ), defined as "an individual's capability to function effectively in situations characterized by cultural diversity” (Ang \& Van Dyne, 2008, p. 3), has been identified as one of the most promising approaches to understanding cross-cultural competence (Matsumoto \& Hwang, 2013). The CQ model comprises four subscales: (1) Metacognitive CQ - conscious cultural awareness during intercultural interactions, (2) Cognitive CQ - knowledge of cultural norms, practices, and conventions, (3) Motivational CQ - attention and energy toward cultural differences, and (4) Behavioral CQ - ability to act appropriately during intercultural interactions in terms of verbal and nonverbal behavior. CQ is a consistent predictor of intercultural adjustment (Leung, Ang, \& Tan, 2014; Lin, Chen, \& Song, 2012) and Engle and Crowne (2014) suggested that a greater need for study abroad support services accompanies lower levels of CQ. If students have little intercultural awareness, knowledge, motivation or ability, they may be more comfortable selecting a study abroad program that is less immersive. Thus, individuals who prefer the exported campus model were expected to have lower CQ (on all four subscales) than those who prefer a more immersive experience.

\section{Method}

\section{Participants}

A total of 188 students signed up to participate in this study. Students with previous college level study abroad experience were dropped from the analysis, including five international students and nine domestic students. The remaining 174 respondents included 63 male and 111 female undergraduate students $(83.4 \%$ first year, $10.7 \%$ sophomores, $5.3 \%$ juniors, and $.6 \%$ seniors) whose participation fulfilled a research requirement. They ranged in age from 18 to 23 years $(M=18.63)$ and attended a small liberal arts university in Southern California. At this institution more than $50 \%$ of students participate in one of several study abroad options, including exported campus, direct enrollment, and hybrid programs.

This group represented a wide range of income levels and, in terms of race/ethnicity, selfidentified as $62.1 \%$ White, $16.7 \%$ Latino/a, 8.6\% Asian, 5.2\% Multiethnic, $3.4 \%$ Middle Eastern/North African, 2.9\% Black, and .6\% Native American. Academic majors and intended majors included natural sciences $(26.3 \%)$, social sciences $(23.5 \%)$, business $(23.0 \%)$, humanities $(13.8 \%)$, and undecided or other (12.6\%). A total of $23 \%$ of participants reported speaking a language other than English at home and $81.6 \%$ had traveled outside of the United States, the majority of whom as tourists $(96.5 \%)$.

\section{Instruments and Procedure}

Students who signed up to participate in this study were contacted via e-mail and asked to voluntarily complete an anonymous, on-line survey. The link to the survey was included in the initial e-mail message and a follow-up reminder message. The questionnaire used in this study took approximately 20 minutes to complete and assessed basic demographic information, preferred model of study abroad, and potential predictors of model preference. The demographic items included age, gender, race/ethnicity, year in college, academic major, family income, heritage language, and previous travel experience. Given the potential influence of minority status on preferred model, race/ethnicity was coded in terms of Students of Color and White students. In addition to the demographic items, 
the questionnaire assessed several personality variables (self-efficacy, tolerance of ambiguity, and adventurousness) and intercultural variables (intercultural communication apprehension, ethnocentrism, language learning interest, and cross-cultural competence). The wording and number of the Likert anchor labels on some of the original scales were modified slightly in order to create greater consistency across measures.

\section{Study abroad model preference.}

Preference for the exported campus as opposed to a more immersive model of study abroad was assessed through the following choice item:

Imagine that you had the time and money to study abroad in the country of your choice, and that you have two types of study abroad programs to choose from:

TYPE A: You study and live with other [NAME OF UNIVERSITY] students. You attend classes (in English) on a campus run by the [NAME OF UNIVERSITY] in your host country.

TYPE B: You study and live with students from many countries including students from your host country. You attend classes (in English) at a host country university.

If you had to choose between these two TYPES of study abroad programs, which would you choose? (click one)

Respondents were specifically instructed not to consider time or cost since these have been identified as factors influencing students' selection of study abroad programs (He \& Chen, 2010). Language of instruction was held constant to allow participants to respond to the study abroad model without being influenced by their own language ability.

General Self-Efficacy Scale.

Schwarzer and Jerusalem's (1995) General Self-Efficacy Scale (GSES; Cronbach's alpha = .90) is a 10-item measure of perceived self-efficacy in coping with novel or difficult tasks. Higher scores indicate greater self-efficacy. The internal consistency and criterion-related validity of this measure has been documented (Jerusalem \& Schwarzer, 1992; Leganger, Kraft, \& Røysamb, 2000; Luszczynska, Scholz, \& Schwarzer, 2005; Schwarzer \& Jerusalem, 1995).

Ambiguity Tolerance Scale.

McLain's (2009) Multiple Stimulus Types Ambiguity Tolerance Scale (MSTAT - II; Cronbach's alpha $=.80)$ is a 13-item measure of ambiguity tolerance "as an orientation, ranging from aversion to attraction, toward stimuli that are complex, unfamiliar, and insoluble” (p. 975). There is an extensive literature supporting the reliability, validity, and factor structure of this measure (see Furnham \& Marks, 2013 for a review). Higher scores indicate greater tolerance for ambiguity.

IPIP Adventurousness subscale.

The 10-item Adventurousness measure from the International Personality Item Pool (IPIP ADV; Goldberg, 1999; Cronbach's alpha = .81), assesses the adventurousness facet of the Five Factor Model Openness to Experience subscale. Higher scores indicate greater adventurousness. Previous studies support the reliability, validity, and factor structure of this measure (Ehrhart, Roesch, Ehrhart, \& Kilian, 2008; Johnson, 2014; Lim \& Ployhart, 2006). 
Intercultural Communication Apprehension.

Neuliep and McCroskey's (1997a) Personal Report of Intercultural Communication Apprehension (PRICA; Cronbach's alpha $=.94$ ) assesses anxiety associated with real or anticipated intercultural interaction. The higher the score on this 14-item scale, the greater apprehension indicated. Previous research has demonstrated the internal consistency of this measure (Lin \& Rancer, 2003; Neulip \& Ryan, 1998).

\section{Generalized Ethnocentrism Scale.}

Neuliep and McCroskey's (1997b) Generalized Ethnocentrism Scale (GENE; Cronbach's alpha $=.92)$ is a 22-item measure that assesses individual differences in ethnocentrism, regardless of cultural background. Higher scores indicate greater ethnocentrism. Several studies have reported strong support for the reliability and validity of the GENE, (Neuliep, 2002; Neuliep, Chaudoir, \& McCroskey, 2001; Neuliep, \& McCroskey, 1997b).

Interest in Foreign Languages Scale.

Hembroff and Rusz' (1993) Interest in Foreign Languages Scale (IFLS; Cronbach's alpha = .88) is a 6-item measure that assesses attitudes about the value of language learning. The reliability and validity of this measure has been documented (Goldstein \& Kim, 2006; Hembroff \& Rusz, 1993; Kim \& Goldstein, 2005). Higher scores indicate a greater value placed on language learning.

Cultural Intelligence Scale.

Ang, Van Dyne, Koh, Ng, Templer, Tay, \& Chandrasekar's (2007) Cultural Intelligence Scale (CQS) is a 20-item measure of cross-cultural competence, which contains the Metacognitive, Cognitive, Motivational, and Behavioral subscales. Higher scores indicate greater CQ on each subscale. There is an extensive literature supporting the reliability, validity, and factor structure of this measure (e.g., Ang, Van Dyne, Koh, Ng, Templar, Tay, \& Chandrasekar, 2007; Matsumoto \& Hwang, 2013; Van Dyne, Ang, \& Koh, 2008; Van Dyne, Ang, Ng, Rockstuhl, Tan, \& Koh, 2012). In the current study, these items yielded Cronbach's alphas of $.88, .89, .83$, and .87 for the Metacognitive, Cognitive, Motivational, and Behavioral subscales respectively.

\section{Results}

Average score composites were calculated and zero order correlations were computed for each of the predictor variables (see Table 1). The role of demographic variables in study abroad model preference was investigated in order to determine which, if any, of these variables to include in subsequent analyses. One way ANOVA indicated no significant difference between groups for income $F(1,172)=.76, p=$ NS. Chi Square analysis indicated that preference for study abroad model did not differ by gender, $\chi^{2}(1, N=174)=0.07, p=$ NS or heritage language $\chi^{2}(1, N=174)=0.30, p=$ NS. There was a significant difference for race/ethnicity $\chi^{2}(1, N=174)=3.68, p<.05$ in that Students of Color had a greater tendency to select the more immersive model over the exported campus model $(73 \%$ vs. $27 \%)$ than did White students (58\% vs. $42 \%)$. Thus, race/ethnicity was included in the subsequent analysis.

A discriminant analysis was conducted to identify predictors of preference for study abroad model (see Table 2). Predictors were race/ethnicity, self-efficacy (GSES), ambiguity tolerance (MSTAT - II), adventurousness (IPIP ADV), intercultural communication apprehension (PRICA), ethnocentrism (GENE), language learning interest (IFLS), and the four cultural intelligence (CQ) 
subscales. The log determinants were quite similar and the nonsignificant result of Box's M test indicated that the assumption of equality of covariance matrices was met. The overall Chi-square test was significant (Wilks $\lambda=.83$, Chi-square $=31.84, \mathrm{df}=11$, Canonical correlation $=.42, \mathrm{p}<.005$ ). Closer analysis of the structure matrix revealed five significant predictors: IPIP ADV (.67), GENE (-.44), IFLS (.34), CQ Motivation (.37), and CQ Metacognitive (.69). Group differences on the measures of MSTAT-II, PRICA, CQ Cognitive, and CQ Behavioral approached significance and were in the expected direction. There was no significant difference between groups on the GSES. Overall, $62.4 \%$ of cases were correctly classified.

Table 1.Interscale Correlations for Predictor Variables

\begin{tabular}{|c|c|c|c|c|c|c|c|c|c|c|c|}
\hline Variable & Mean & SD & 1 & 2 & 3 & 4 & 5 & 6 & 7 & 8 & 9 \\
\hline 1. GSES & 5.34 & 0.84 & & & & & & & & & \\
\hline 2. MSTAT-II & 4.41 & 0.75 & $.32 * * *$ & & & & & & & & \\
\hline 3. IPIP ADV & 4.60 & 0.89 & $.24^{* *}$ & $.46^{* * *}$ & & & & & & & \\
\hline 4. PRICA & 2.52 & 0.94 & $\begin{array}{l}- \\
.38 * * *\end{array}$ & $.34 * * *$ & $.38 * * *$ & & & & & & \\
\hline 5. GENE & 2.55 & 0.78 & .13 & $-.22 * *$ & $.35 * * *$ & $.54 * * *$ & & & & & \\
\hline 6. IFLS & 5.79 & 1.06 & $.31 * * *$ & .15 & $.37 * * *$ & $.39 * * *$ & $.62 * * *$ & & & & \\
\hline $\begin{array}{l}\text { 7. CQ- } \\
\text { Motivational }\end{array}$ & 5.40 & 0.91 & $.31 * * *$ & $.28 * * *$ & $.44 * * *$ & - $61 * * *$ & $.50 * * *$ & $.38 * * *$ & & & \\
\hline 8. CQ- Cognitive & 3.94 & 1.27 & $.18^{*}$ & $.22^{* *}$ & $.32 * * *$ & $.27 * * *$ & -.07 & $.16^{*}$ & $.39 * * *$ & & \\
\hline $\begin{array}{l}\text { 9.CQ- } \\
\text { Metacognitive }\end{array}$ & 4.93 & 1.09 & $.23^{* *}$ & $.36 * * *$ & $.42 * * *$ & $.42 * * *$ & $.43 * * *$ & $.39 * * *$ & $.49 * * *$ & $.45 * * *$ & \\
\hline 10.CQ-Behavioral & 4.59 & 1.01 & $.22 * *$ & $.21 * *$ & $.28 * * *$ & $-.23 * *$ & $-.25^{* *}$ & $.34 * * *$ & $.30 * * *$ & $.26 * *$ & $.57 * * *$ \\
\hline
\end{tabular}

Note: Items rated on a 7 point scale. ${ }^{*} \mathrm{p}<.05 .{ }^{* * p} \mathrm{p}<.01 .{ }^{* * *} \mathrm{p}<.001$

Table 2. Mean Comparisons of Predictors by Preferred Model of Study Abroad

\begin{tabular}{llll}
\hline $\begin{array}{lll}\text { Background Variable } \\
\text { Race (Students of Color) }\end{array}$ & Exported Campus Model & Immersion Model & F value \\
& .29 & .43 & 3.43 \\
Personality Variables & & & \\
GSES & 5.42 & 5.32 & .59 \\
MSTAT- II & 4.28 & 4.49 & 3.38 \\
IPIP ADV & 4.25 & 4.79 & $16.38^{* * *}$ \\
& & & \\
Intercultural Variables & & & \\
PRICA & 2.69 & 2.42 & 3.41 \\
GENE & 2.76 & 2.44 & $6.94^{* *}$ \\
IFLS & 5.59 & 5.93 & $4.26^{*}$ \\
CQ-Mot & 5.19 & 5.50 & $4.92^{*}$ \\
CQ-Cog & 3.74 & 4.04 & 2.27 \\
CQ-Meta & 4.48 & 5.17 & $17.36^{* * *}$ \\
CQ-Behav & 4.41 & 4.69 & 3.02 \\
\hline
\end{tabular}

Note: Items rated on a 7 point scale. Race/ethnicity was coded: White students $=0$ and Students of Color $=1$.

${ }^{*} p<.05 .{ }^{* *} p<.01 . * * * p<.001$.

\section{Discussion}

These findings indicate that students who prefer the exported campus model of study abroad differ in meaningful ways from those who prefer a more immersive experience. First, Students of Color were significantly more likely than White students to prefer the more immersive model, although 
race/ethnicity did not remain a significant predictor in the discriminant analysis. It seems likely that Students of Color generally have more experience than White students with negotiating intergroup differences and may thus be less hesitant to do so in a study abroad context. In addition, it may be that Students of Color view the exported campus community as less of a safety net than do their White peers. Clearly, there is need for a better understanding of role of race/ethnicity in study abroad participation in general (see, for example, Salisbury, Paulsen, \& Pascarella, 2011) and, it would seem, in choice of program as well.

As predicted, students who preferred the exported campus model scored significantly higher on ethnocentrism and lower on measures of adventurousness, language learning interest, motivational CQ, and metacognitive CQ than those who preferred the more immersive model. These students also scored higher on intercultural communication apprehension, and lower on tolerance of ambiguity, cognitive CQ, and behavioral CQ, although these differences only approached significance in the discriminant analysis. Contrary to prediction, there was no significant difference between groups in general self-efficacy. Future research might investigate the role of domain specific forms of selfefficacy in preference for model of study abroad, such as self-efficacy in intercultural communication (Peterson, Milstein, Chen, \& Nakazawa, 2011). This strategy is supported by the fact that motivational CQ, which deals in part with respondents' confidence in intercultural situations, was a significant predictor of model preference in the current study.

The findings of this study have implications for advising potential study abroad students, conducting pre-departure training, and developing in-country programming. These implications may be clarified by viewing the predictors of preference for study abroad model in terms of traits (such as adventurousness), attitudes (such as ethnocentrism and language learning interest), and skills (such as CQ). According to Hannigan (1990, p. 89-90), "Overall, there are three categories into which these factors [involved in successful cross-cultural functioning] can be classified: skills, attitudinal factors, and personality traits. The first two categories are directly related to the training process, the implication being that persons can develop the necessary skills in order to function in a different culture and that attitudes can change. Personality traits are generally perceived as previously established in the individual's life or inherent. Therefore, this last factor relates to the selection process."

As a facet of a relatively stable Five Factor Model trait (Roberts \& DelVeccio, 2000), adventurousness may be more relevant to advising students in selecting a study abroad program than to designing training or interventions. In fact, recent research has indicated that there may be a genetic basis for the related trait of novelty seeking (Heck, et al., 2009), further supporting the stability of this characteristic. Students with low levels of adventurousness appear to prefer, and might be best suited to, the exported campus model. Moreover, for many of these students the choice may not be between an exported campus program and a more immersive experience but between an exported campus program and not studying abroad at all. Future research might investigate strategies for enhancing the intercultural contact experiences of those with low adventurousness or other personality traits that reduce the potential for culture learning.

In contrast to trait-based characteristics, the intercultural attitudes and skills characterizing those who preferred the exported campus model are an appropriate focus for pre-departure and in-country training. Interventions aimed at reducing ethnocentrism are central to sojourner success in that 
ethnocentrism limits culture-specific and culture-general understanding (Wiseman, Hammer, \& Nishida, 1989) and creates misperceptions about the behavior of culturally different individuals (Gudykunst \& Kim, 1997). Coursework and simulations designed to help students gain cultural knowledge and understand cultural similarities and differences have been successful in reducing ethnocentrism (see, for example, Pettijohn \& Naples, 2009). Pre-departure and in-country training with this focus may significantly increase culture learning for participants of exported campus programs.

Interest in language learning is also central to culture learning. Language competence is a critical component of effective intercultural interactions (Chen \& Starosta, 1996; Masgoret \& Ward, 2006; Redmond \& Bunyi, 1991; Sercu, 2002; Wilson, Ward, \& Fischer, 2013), intercultural sensitivity (Olson and Kroeger, 2001), and successful cross-cultural adjustment (Ward \& Kennedy, 1993). Wilson, Ward, and Fischer (2013) suggested that language proficiency allows for greater opportunities for culture learning and thus improved sociocultural adaptation. Given the results of this study, it seems particularly important to emphasize the value of language learning in pre-departure and in-country training for participants of exported campus programs.

Students who preferred the exported campus model had significantly lower levels of metacognitive and motivational CQ than those who preferred the more immersive model. Even if interventions successfully improve intercultural attitudes, the culture learning of exported campus participants may be severely limited unless they have developed adequate cultural intelligence. Students who preferred the exported campus model and those who preferred a more immersive experience differed to a greater extent on metacognitive CQ than on any other variable tested in this study. Metacognitive CQ involves the ability to strategically plan for intercultural interactions, awareness of how culture influences one's own and others' behavior in real time, and the ability to evaluate and modify mental models based on intercultural experience (Van Dyne, Ang, Ng, Rockstuhl, Tan, \& Koh, 2012). Research indicates that CQ can be significantly enhanced through intercultural training and structured experiences (see, for example, Earley \& Peterson, 2004; Ng, Van Dyne, \& Ang, 2009; Şahin, Gurbuz, \& Köksal, 2014), interventions which should clearly be a priority for predeparture and in-country training targeting exported campus participants. It may be particularly useful to teach these students the metacognitive skill of cultural perspective taking, which focuses on the ability to consider the ways in which culture may shape others' behavior (Mor, Morris, \& Joh, 2013).

In addition to implications for intercultural training, these results suggest that institutions seeking to expand their enrollment in, and prepare students for, study abroad might consider prioritizing reducing ethnocentrism, increasing interest in language learning, and building cultural intelligence through programs that are available to all students as part of their regular curriculum and extracurricular activities.

Finally, pre-existing differences between students who prefer different models of study abroad are relevant to conducting and interpreting study abroad outcome research. Clearly these differences must be taken into consideration when comparing and evaluating the intercultural competence or language proficiency gains from various types of programs. For individuals with low adventurousness or high ethnocentrism, for example, a small change in intercultural competence may be of equal value to a greater change among those with high adventurousness or low ethnocentrism. 


\section{Limitations and Future Research}

There are several limitations to this study which should be addressed in future research. The primary weakness of this design was its focus on program preference in a hypothetical context as opposed to examining pre-departure characteristics of students actually enrolled in a variety of study abroad models. In addition, students were presented with two choices representing relative extremes on the continuum of study abroad models, whereas currently many programs are best categorized as a hybrid of these models. It might be useful to investigate predictors of preference for specific components of study abroad models. Engle and Engle (2003), for example, classified study abroad models into five levels of immersion based on a variety of factors including, but not limited to, duration, language used in course work, and inclusion of home stay housing.

The participants in this study were drawn from a single liberal arts university in Southern California, which may be unrepresentative of U.S. tertiary institutions in terms of level of diversity and access to study abroad programs. Furthermore, the majority of participants had traveled outside of the U.S. as tourists. Although this is not surprising given this university's proximity to Mexico, this level of intercultural experience may have influenced students' evaluation of study abroad models. Future research should involve participants with greater variability in intercultural experience in order to assess the role of previous travel in preference for study abroad model.

The predictor variables only partially explained preference for study abroad models, and thus, several other potential predictor variables might be investigated. Involvement in campus life, for example, may affect study abroad preferences. Based on their analysis of data from the CIRP Freshman Survey, Rust, Dhanatya, Furuto, and Kheiltash (2008), reported that students with greater college involvement in social, academic, community, political, and diversity activities were more likely to intend to study abroad. It may be that type of campus involvement is predictive of study abroad model preference as well. Students with greater on-campus social involvement, for example, may be more attracted to the exported campus model. The opinions of parents clearly influence study abroad choices, particularly concerning perceptions of safety (Desruisseaux, 1998). Little is known, however, about the role of parents in shaping preference for type of study abroad program. In addition, it would also be useful to investigate the role of peers in the program selection process, particularly those who have participated in study abroad, as many institutions involve returnees in study abroad recruitment or orientation activities. Finally, it may be of value to investigate the influence of students' expectations of the intercultural adjustment process on preference for study abroad program type, in that lower CQ is associated with a less sophisticated understanding of this process (Goldstein \& Keller, 2015); these expectations may deter students from selecting a more immersive model.

This study contributes to the information available to study abroad professionals seeking to guide students in selecting programs that are best suited to their individual characteristics and needs. In addition, it identifies critical attitudes and skills to target for improvement in pre-departure and incountry training that may otherwise limit the culture learning of exported campus students. With better understanding of the traits, attitudes, and skills of students who prefer the exported campus model, these programs can better fulfill the important function of facilitating participants' successful encounters with the host culture. 


\section{References}

Ang, S., \& Van Dyne, L., (2008). Conceptualization of cultural intelligence: Definition, distinctiveness, and nomological network. In S. Ang, \& L. Van Dyne, (Eds.) Handbook on Cultural Intelligence: Theory, Measurement and Applications (pp. 3-15). Armonk, NY: M.E. Sharpe.

Ang, S., Van Dyne, L., Koh, C., Ng, K. Y., Templer, K. J., Tay, C., \& Chandrasekar, N. A. (2007). Cultural intelligence: Its measurement and effects on cultural judgment and decision making, cultural adaptation and task performance. Management and Organization Review, 3(3), 335-371.

Bakalis, S., \& Joiner, T. A. (2004). Participation in tertiary study abroad programs: The role of personality. The International Journal of Educational Management, 18(4/5), 286 - 291.

Bandura, A. (1977). Self-efficacy: Toward a unifying theory of behavior change. Psychological Review, 84(2), 191-215.

Bandura, A., \& Locke, E. A. (2003). Negative self-efficacy and goal effects revisited. Journal of Applied Psychology, 88(1), 87-99.

Bizumic, B., \& Duckitt, J. (2012). What is and is not ethnocentrism? A conceptual analysis and political implications. Political Psychology, 33(6), 887-909.

Budner S. (1962). Intolerance of ambiguity as a personality variable. Journal of Personality, 30, 29-50.

Caligiuri, P. M. (2000). Selecting expatriates for personality characteristics: A moderating effect of personality on the relationship between host national contact and cross-cultural adjustment. MIR: Management International Review, 40(1), 61-80.

Carlson, J. S., Burn, B. B., Useem, J., \& Yachimowicz, D. (1990). Study abroad: The experience of American undergraduates. New York: Greenwood.

Chen, C. C., \& Hooijberg, R. (2000). Ambiguity intolerance and support for valuing-diversity interventions. Journal of Applied Social Psychology, 30(11), 2392-2408.

Chen, G.-M., \& Starosta, W. J. (1996). Intercultural communication competence: A synthesis. Communication Yearbook, 19, 353-383.

Cui, G., \& Awa, N. E. (1992). Measuring intercultural effectiveness: An integrative approach. International Journal of Intercultural Relations, 16(3), 311-328.

Deardorff, D. K. (2006). Identification and assessment of intercultural competence as a student outcome of internationalization. Journal of Studies in International Education, 10(3), 241-266.

Desruisseaux, P. (1998). What parents should know about study-abroad programs. Chronicle of Higher Education, 44(40), 1.

Earley, P. C., \& Peterson, R. S. (2004). The elusive cultural chameleon: Cultural intelligence as a new approach to intercultural training for the global manager. Academy of Management Learning \& Education, 3(1), 100-115.

Ehrhart, K. H., Roesch, S. C., Ehrhart, M. G., \& Kilian, B. (2008). A test of the factor structure equivalence of the 50-Item IPIP Five-Factor Model measure across gender and ethnic groups. Journal of Personality Assessment, 90(5), 507-516.

Engle, L., \& Engle, J. (2003). Study abroad levels: Toward a classification of program types. Frontiers: The Interdisciplinary Journal of Study Abroad, 9, 1-20.

Engle, R. L., \& Crowne, K. A. (2014). The impact of international experience on cultural intelligence: An application of contact theory in a structured short-term programme. Human Resource Development International, 17(1), 30-46.

Fry, G. W., Paige, R. M., Jon, J.-E., Dillow, J., \& Nam, K.-A. (2009). Study Abroad and its Transformative Power. Occasional Papers on International Educational Exchange 32. Portland, ME: Council on International Educational Exchange.

Furnham, A., \& Marks, J. (2013). Tolerance of ambiguity: A review of recent literature. Psychology, 4(9), 717-728. 
Goldberg, L. R. (1999). A broad-bandwidth, public domain, personality inventory measuring the lower-level facets of several five-factor models. In I. Mervielde, I. Deary, F. De Fruyt, and F. Ostendorf (Eds.), Personality Psychology in Europe, Vol. 7 (pp. 7-28). Tilburg University Press, Tilburg, Netherlands.

Goldstein, S. B., \& Keller, S. R. (2015). U.S. college students' lay theories of culture shock. International Journal of Intercultural Relations, 47, 187-194.

Goldstein, S. B., \& Kim, R. I. (2006). Predictors of U. S. college students' participation in study abroad programs: A longitudinal study. International Journal of Intercultural Relations, 30(4), 507-521.

Gudykunst, W. B., \& Kim, Y.Y. (1997). Communicating with strangers: An approach to intercultural communication. New York: McGraw-Hill.

Hannigan, T. F. (1990). Traits, attitudes, and skills that are related to intercultural effectiveness and their implications for cross-cultural training: A review of the literature. International Journal of Intercultural Relations, 14(1), 89-111.

Hanouille, L., \& Leuner, P. (2001). Island programs: Myths and realities in international education. World Education News \& Reviews, 14(1). Retrieved from http://wenr.wes.org/2001/01/ewenr-janfeb-2001-feature/

Harrison, J. K., Chadwick, M., \& Scales, M. (1996). The relationship between cross-cultural adjustment and the personality variables of self-efficacy and self-monitoring. International Journal of Intercultural Relations, 20(2), 167-188.

He, N., \& Chen, R. J. C. (2010). College students' perceptions and attitudes toward the selection of study abroad programs. International Journal of Hospitality \& Tourism Administration, 11, 347-359.

Hechanova-Alampay, R., Beehr, T. A., Christiansen, N. D., \& van Horn, R. K. (2002). Adjustment and strain among domestic and international student sojourners: A longitudinal study. School Psychology International, 23(4), 458-474.

Heck, A., Lieb, R., Ellgas, A., Pfister, H., Lucae, S., Roeske, D., . . Ising, M. (2009). Investigation of 17 candidate genes for personality traits confirms effects of the HTR2A gene on novelty seeking. Genes, Brain \& Behavior, 8(4), 464-472

Hembroff, L. A., \& Rusz, D. L. (1993). Minorities and overseas studies programs: Correlates of differential participation. Occasional Papers on International Educational Exchange: Research Series 30. New York: Council on International Educational Exchange.

Jerusalem, M., \& Schwarzer, R. (1992). Self-efficacy as a resource factor in stress appraisal processes. In R. Schwarzer (Ed.), Self-efficacy: Thought control of action (pp. 195-213). Washington, DC: Hemisphere.

Johnson, J. A. (2014). Measuring thirty facets of the Five Factor Model with a 120-item public domain inventory: Development of the IPIP-NEO-120. Journal of Research in Personality, 51, 78-89.

Kim, R. I., \& Goldstein, S. B. (2005). Intercultural attitudes predict favorable study abroad expectations of American college students. Journal of Studies in International Education, 9(3), 265-278.

Leganger, A., Kraft, P., \& Røysamb, E. (2000). Perceived self-efficacy in health behaviour research: Conceptualisation, measurement and correlates. Psychology \& Health, 15(1), 51-69.

Leong, C.-H., \& Ward, C. (2000). Identity conflict in sojourners. International Journal of Intercultural Relations, 24, 763-776.

Leung, K., Ang, S., \& Tan, M. L. (2014). Intercultural Competence. Annual Review of Organizational Psychology and Organizational Behavior, 1, 489-519.

Li, A., \& Gasser, M. B. (2005). Predicting Asian international students' sociocultural adjustment: A test of two mediation models. International Journal of Intercultural Relations, 29(5), 561-576.

Li, M., Olson, J. E., \& Frieze, I. H. (2013). Students' study abroad plans: The influence of motivational and personality factors. Frontiers: The Interdisciplinary Journal of Study Abroad, 23, 73-89.

Lim, B.-C., \& Ployhart, R. E. (2006). Assessing the convergent and discriminant validity of Goldberg's 
International Personality Item Pool: A multitrait-multimethod examination, Organizational Research Methods, 9, 29-54.

Lin, Y., Chen, A. S., \& Song, Y. (2012). Does your intelligence help to survive in a foreign jungle? The effects of cultural intelligence and emotional intelligence on cross-cultural adjustment. International Journal of Intercultural Relations, 36(4), 541-552.

Lin, Y., \& Rancer, A. S. (2003). Ethnocentrism, intercultural communication apprehension, intercultural willingness-to-communicate, and intentions to participate in and intercultural dialogue program: Testing a proposed model. Communication Research Reports, 20, 62-72.

Lloyd, S., \& Härtel, C. (2010). Intercultural competencies for culturally diverse work teams. Journal of Managerial Psychology, 25(8), 845-875.

Logan, S., Steel, Z., \& Hunt, C. (2015). Investigating the effect of anxiety, uncertainty and ethnocentrism on willingness to interact in an intercultural communication. Journal of CrossCultural Psychology, 46(1), 39-52.

Luszczynska, A., Gutiérrez-Doña, B., \& Schwarzer, R. (2005). General self-efficacy in various domains of human functioning: Evidence from five countries. International Journal of Psychology, 40(2), 8089.

Luszczynska, A., Scholz, U., \& Schwarzer, R. (2005). The general self-efficacy scale: Multicultural validation studies. The Journal of Psychology, 139(5), 439-457.

Maharaja, G. G. (2009). An "island" study abroad program and its impact on the intercultural sensitivity and crosscultural adaptability of its participants: Perspectives from a research intensive university. (Doctoral dissertation) Retrieved from http://0search.proquest.com.books.redlands.edu/docview/815958894?accountid=14729 $\quad$ (815958894; ED512764).

Matsumoto, D., \& Hwang, H.C. (2013). Assessing cross-cultural competence: A review of available tests. Journal of Cross-Cultural Psychology, 44(6), 849-873.

McCrae, R.R., \& Costa, P.T. (1987) Validation of the five-factor model of personality across instruments and observers. Journal of Personality and Social Psychology, 52, 81-90.

McLain, D. L. (2009). Evidence of the properties of an ambiguity tolerance measure: The multiple stimulus types ambiguity tolerance scale-II (MSTAT-II). Psychological Reports, 105, 975-988.

Masgoret, A.-M., \& Ward, C. (2006). Culture learning approaches to acculturation. In D. L. Sam, \& J. W. Berry (Eds.), The Cambridge handbook of acculturation psychology (pp. 58-77). Cambridge, UK: Cambridge University Press.

Mor, S., Morris, M., \& Joh, J. (2013). Identifying and training adaptive cross-cultural management skills: The crucial role of cultural metacognition. Academy of Management Learning \& Education, 12(3), 453-475.

Nelson, L. R., \& Rapoport, A. (2005). Russian civic education and social studies education at Purdue University. International Journal of Social Education, 20(2), 99-114.

Neuliep, J. W. (2002). Assessing the reliability and validity of the Generalized Ethnocentrism Scale. Journal of Intercultural Communication Research, 31, 201-215.

Neuliep, J. W., Chaudoir, M., \& McCroskey, J. C. (2001). A cross-cultural comparison of ethnocentrism among Japanese and United States college students. Communication Research Reports, 18, 137146.

Neuliep, J. W., \& McCroskey, J. C. (1997a). The development of intercultural and interethnic communication apprehension scales. Communication Research Reports, 14, 145-156.

Neuliep, J. W., \& McCroskey, J. C. (1997b). The development of a U.S. and generalized ethnocentrism scale. Communication Research Reports, 14, 385-398.

Neuliep, J. W., \& Ryan, D. J. (1998). The influence of intercultural communication apprehension and socio-communicative orientation on uncertainty reduction during initial cross-cultural interaction. 
Communication Quarterly, 46, 88-99.

Ng, K. Y., Van Dyne, L., \& Ang, S. (2012). Cultural intelligence: A review, reflections, and recommendations for future research. In A. M. Ryan, F.T.L. Leong, \& F. L. Oswald (Eds.), Conducting multinational research: Applying organizational psychology in the workplace (pp. 29-58). Washington, DC: American Psychological Association.

Norris, E. M., \& Dwyer, M. (2005). Testing assumptions: The impact of two study abroad program models. Frontiers: The Interdisciplinary Journal of Study Abroad, 11, 121-142.

Olson, C. L., \& Kroeger, K. R. (2001). Global Competency and intercultural sensitivity. Journal of Studies in International Education, 5, 116-137.

Open Doors (2014). Report on international educational exchange. Washington, DC: Institute of International Education.

Organisation for Economic Co-operation and Development [OECD](2014). Education at a glance in 2014: Highlights. OECD Publishing. Retrieved from: http://dx.doi.org/10.1787/eag highlights2014-en

Paige, R. M., \& Vande Berg, M. (2012). Why students are and are not learning abroad: A review of recent research. In M. Vande Berg, R.M. Paige, \& K. H. Lou (Eds.), Student learning abroad: What our students are learning, what they're not, and what we can do about it (pp. 29-58). Sterling, VA: Stylus.

Peterson, J. C., Milstein, T., Chen, Y.-W., \& Nakazawa, M. (2011). Self-efficacy in intercultural communication: The development and validation of a sojourner's scale. Journal of International and Intercultural Communication, 4(4), 290-309.

Pettijohn, T. F., \& Naples, G. M. (2009). Reducing ethnocentrism in U.S. college students by completing a cross-cultural psychology course. The Open Social Science Journal, 2, 1-6.

Redmond, M. V., \& Bunyi, J. M. (1991). The relationship of intercultural communication competence with stress and the handling of stress as reported by international students. International Journal of Intercultural Relations, 17, 235-254.

Roberts, B. W., \& DelVecchio, W. F. (2000). The rank-order consistency of personality traits from childhood to old age: A quantitative review of longitudinal studies. Psychological Bulletin, 126(1), 325.

Rust, V., Dhanatya, C., Furuto, L. H. L., \& Kheiltash, O. (2008). Student involvement as predictive of college freshmen plans to study abroad. Frontiers: The Interdisciplinary Journal of Study Abroad, 15, 116.

Şahin, F., Gurbuz, S., \& Köksal, O. (2014). Cultural intelligence (CQ) in action: The effects of personality and international assignment on the development of CQ. International Journal of Intercultural Relations, 39, 152-163.

Salisbury, M. H., Paulsen, M. B., \& Pascarella, E. T. (2011). Why do all the study abroad students look alike? Applying an integrated student choice model to explore differences in the factors that influence white and minority students' intent to study abroad. Research in Higher Education, 52(2), 123-150.

Schwarzer, R., \& Jerusalem, M. (1995). Generalized Self-Efficacy scale. In J. Weinman, S. Wright, \& M. Johnston, Measures in health psychology: A user's portfolio. Causal and control beliefs (pp. 35-37). Windsor, UK: NFER-NELSON.

Searle, W., \& Ward, C. (1990). The prediction of psychological and sociocultural adjustment during cross-cultural transitions. International Journal of Intercultural Relations, 14(4), 449-464.

Sercu, L. (2002). Autonomous learning and the acquisition of intercultural communicative competence: Some implications for course development. Language, Culture \& Curriculum, 15, 61-74.

Strauss, J. P., Connerley, M. L., \& Ammermann, P. A. (2003). The "threat hypothesis," personality, and attitudes toward diversity. Journal of Applied Behavioral Science, 39, 32-52. 
Stroud, A. H. (2010). Who plans (not) to study abroad? An examination of U.S. student intent. Journal of Studies in International Education, 14(5), 491-507.

Sumner, W. G. (1906). Folkways. Boston: Ginn.

Tretheway, M. W. (1992). Island programs: The UBC experience with a summer program in France. Journal of Business Administration, Fall/Winter, 345-352.

Uhlmann, E. L. (2012). American psychological isolationism. Review of General Psychology, 16(4), 381 390.

Van der Zee, K., \& van Oudenhoven, J. P. (2013). Culture shock or challenge? The role of personality as a determinant of intercultural competence. Journal of Cross-cultural Psychology, 44(6), 928-940.

Van Dyne, L., Ang, S., \& Koh, C. (2008). Development and validation of the CQS: The cultural intelligence scale. In S. Ang, \& L. Van Dyne, (Eds.) Handbook on Cultural Intelligence: Theory, Measurement and Applications (pp. 16-38). Armonk, NY: M.E. Sharpe.

Van Dyne, L., Ang, S., Ng, K.-Y., Rockstuhl, T., Tan, M.L., \& Koh, C. (2012). Sub-dimensions of the four factor model of cultural intelligence: Expanding the conceptualization and measurement of cultural intelligence (CQ). Social and Personal Psychology: Compass, 6(4), 295-313.

Vande Berg, M., Connor-Linton, J., \& Paige, R. M. (2009). The Georgetown Consortium Project: Intervening in student learning abroad. Frontiers: The Interdisciplinary Journal of Study Abroad, 18, 175.

Ward, C., \& Kennedy, A. (1993). Psychological and socio-cultural adjustment during cross-cultural transitions: A comparison of secondary students overseas and at home. International Journal of Psychology, 28(2), 129-147.

Ward, C., Bochner, S., \& Furnham, A. (2001). The psychology of culture shock (2nd ed.).East Sussex, UK: Routledge.

Wilson, J., Ward, C., \& Fischer, R. (2013). Beyond culture learning theory: What can personality tell us about cultural competence? Journal of Cross-Cultural Psychology, 44(6), 900-927.

Wiseman, R. L., Hammer, M. R., \& Nishida, H. (1989). Predictors of intercultural communication competence. International Journal of Intercultural Relations, 13, 349-370.

Wolcott, T. (2013). An American in Paris: Myth, desire, and subjectivity in one student's account of study abroad in France. In C. Kinginger (Ed.) Social and cultural aspects of language learning in study abroad (pp. 127-153). Philadelphia, PA: John Benjamins.

Woolf, M. (2007). Impossible things before breakfast: Myths in education abroad. Journal of Studies in International Education, 11(3/4), 496-509. 